\title{
Decreased Rates of Methionine Synthesis by Methylene Tetrahydrofolate Reductase-deficient Fibroblasts
} and Lymphoblasts

\author{
Gerry R. Boss and Richard W. Erbe, Genetics Unit, Children's Service and \\ Medical Services, Massachusetts General Hospital, Departments of \\ Pediatrics and Medicine, Harvard Medical School, Boston, Massachusetts 02114
}

\begin{abstract}
A B S T RACT Methionine synthesis from homocysteine was measured in intact human fibroblasts and lymphoblasts using a $\left[{ }^{14} \mathrm{C}\right]$ formate label. Seven fibroblast lines and two lymphoblast lines derived from patients with 5,10-methylene tetrahydrofolate reductase deficiency had rates of methionine synthesis that were from 4 to $43 \%$ of normal. When the patients were divided by clinical status into mildly (two patients), moderately (two patients), and severely (three patients) affected, methionine biosynthesis expressed as a percent of control values was 43 and $33 \%, 11$ and $10 \%$, and 7,6 , and $4 \%$, respectively, in fibroblasts. Similar data for the two lymphoblast lines were 36 and $26 \%$ for a mildly and moderately affected patient, respectively. These data are to be contrasted with the measurement of residual enzyme activity in cell extracts which agrees less precisely with the clinical status of the patients. In the presence of normal methionine synthetase activity, the rate of synthesis of methionine from homocysteine is a function of the activity of the enzyme 5,10methylene tetrahydrofolate reductase, and measurement of the methionine biosynthetic capacity of cells deficient in this enzyme accurately reflects the clinical status of the patient from whom the cells were derived.
\end{abstract}

\section{INTRODUCTION}

Deficiency of the enzyme 5,10-methylene tetahydrofolate reductase (EC 1.1.1.68) leads clinically to neurologic dysfunction of variable type and severity, and biochemically to homocystinuria, homocystinemia, and

These studies were presented in part at the Eastern Regional Meeting of the American Federation for Clinical Research, Boston, Mass., October 1980.

Dr. Boss is the recipient of National Research Service Award 5 T32 GM07748 from the National Institute of General Medical Sciences.

Received for publication 8 December 1980 and in revised form 2 February 1981. decreased plasma and intracellular concentrations of methionine (1). The enzyme catalyzes the essentially irreversible reduction of 5,10-methylenetetrahydrofolate $\left(5,10-\mathrm{CH}_{2}-\mathrm{H}_{4} \mathrm{PteGlu}\right)$ to 5-methyltetrahydrofolate (5- $\mathrm{CH}_{3}-\mathrm{H}_{4} \mathrm{PteGlu}$ ) (2). $5-\mathrm{CH}_{3} \mathrm{H}_{4} \mathrm{PteGlu}$ serves as the methyl donor in the conversion of homocysteine $(\mathrm{HC})^{1}$ to methionine (Met) by the cobalamin-dependent enzyme, methionine synthetase. $5,10-\mathrm{CH}_{2}-\mathrm{H}_{4}$ PteGlu reductase deficiency has been shown to result in reduced 5- $\mathrm{CH}_{3}-\mathrm{H}_{4}$ PteGlu levels in serum, erythrocytes, and brain (3), and a diminished proportion of total intracellular folates as $5-\mathrm{CH}_{3}-\mathrm{H}_{4} \mathrm{PteGlu}$ in fibroblasts cultured from these patients (4). Deficiency of $5-\mathrm{CH}_{3}-\mathrm{H}_{4} \mathrm{PteGlu}$ would be expected to result in reduced Met synthetase activity leading to diminished Met biosynthesis, but this has not yet been demonstrated directly although it is implied by two findings. First, skin fibroblasts from $5,10-\mathrm{CH}_{2}-\mathrm{H}_{4} \mathrm{PteGlu}$ reductase-deficient patients grow less rapidly (5) or, under more stringent conditions, not at all (1) when HC replaces Met in culture medium. Second, tissue amino acid analysis reported only for brain and liver of one patient indicated a reduced concentration of Met (6).

Activity of $5,10-\mathrm{CH}_{2}-\mathrm{H}_{4} \mathrm{PteGlu}$ reductase has been measured in crude extracts of skin fibroblasts or leukocytes using a coupled reaction that proceeds in the reverse direction from the physiologic reaction (2). The extent of $5,10-\mathrm{CH}_{2}-\mathrm{H}_{4} \mathrm{PteGlu}$ reductase deficiency measured in this way has correlated imperfectly with the severity of the clinical and metabolic abnormalities in the patients from whom the cells were derived. To test the hypothesis that the clinical and metabolic abnormalities would more closely parallel the degree of secondary disturbance of the Met synthetase reaction, we undertook to measure the Met biosynthetic capacity

${ }^{1}$ Abbreviations used in this paper: HC, homocysteine; PBS, phosphate-buffered saline. 
in a whole cell system of fibroblasts and lymphoblasts by means of a $\left[{ }^{14} \mathrm{C}\right]$ formate label. When applied to cells from seven patients with $5,10-\mathrm{CH}_{2}-\mathrm{H}_{4}$ PteGlu deficiency, this method yielded results that correlate more precisely with the clinical status of the patients from whom the cells were derived than does the measurement of residual enzyme activity in cell extracts. Moreover, they constitute direct demonstration that Met synthesis is reduced by this inherited enzyme defect.

\section{METHODS}

Cell culture. Fibroblast lines were obtained from the patients and control subjects after approval by Human Subjects Committee according to standard procedures and were grown in Eagle's minimum essential medium (Gibco Laboratories, Grand Island Biological Company, Grand Island, N. Y.) supplemented with nonessential amino acids and $10 \%$ fetal bovine serum (Gibco) in an atmosphere of $95 \%$ air and $5 \% \mathrm{CO}_{2}$. The lymphoblastoid cell lines were initiated by Epstein-Barr virus transformation of peripheral blood lymphocytes (7) and were grown in RPMI-1640 (Gibco) supplemented with $15 \%$ fetal bovine serum (Gibco) and $2 \mathrm{mM}$ glutamine in $95 \%$ air and $5 \% \mathrm{CO}_{2}$. Fibroblasts were fed twice a week and lymphoblasts were maintained at a density between $2-10 \times 10^{5}$ cells $/ \mathrm{ml}$. All cells were tested for mycoplasma by means of bioassay and DNA staining methods.

5,10-CH $\mathrm{CH}_{2}-\mathrm{H}_{4}$ PteGlu reductase assay. Fibroblasts were grown to confluency in either glass roller bottles or plastic petri dishes and maintained at confluency for at least $7 \mathrm{~d}$ before harvesting. The cells were released from the surface by trypsinization, washed in Dulbecco's phosphate-buffered saline (PBS) solution, and resuspended at $10^{8} \mathrm{cells} / \mathrm{ml}$ in 0.25 $M$ sucrose. The cells were disrupted by sonication and the crude extract centrifuged at $90,000 \mathrm{~g}$ for $1 \mathrm{~h}$ at $4^{\circ} \mathrm{C}$. Lymphoblasts were kept in logarithmic growth before harvesting by centrifugation and then treated similarly to the fibroblasts.

Extracts were stored at $-60^{\circ} \mathrm{C}$. in small aliquots and thawed only once just before use. The standard $5,10-\mathrm{CH}_{2}-\mathrm{H}_{4} \mathrm{PteGlu}$ reductase assay was performed according to previously described procedures with the cells grown in either Met or Met-free HC-supplemented medium (8) in the direction of 5- $\mathrm{CH}_{3}-\mathrm{H}_{4} \mathrm{PteGlu}$ to $5,10-\mathrm{CH}_{2}-\mathrm{H}_{4} \mathrm{PteGlu}$.

Methionine biosynthesis assay. Fibroblasts were passaged 1:2 $36 \mathrm{~h}$ before assay, and $12 \mathrm{~h}$ before assay were replated at a density of $3 \times 10^{5}$ cells/35-mm plastic petri dish (Falcon Labware, Div. of Becton, Dickinson \& Co., Oxnard, Calif.). $1 \mathrm{~h}$ before assay the standard medium was replaced by $0.6 \mathrm{ml}$ of Met-free minimum essential medium that was supplemented with nonessential amino acids, $200 \mu \mathrm{M}$ DLhomocysteine-thiolactone- $\mathrm{HCl}, 100 \mu \mathrm{M}$ folic acid, $1.5 \mu \mathrm{M}$ hydroxocobalamin and $10 \%$ fetal bovine serum that had been dialyzed for at least $24 \mathrm{~h}$ against a 100 -fold volume of $0.9 \%$ $\mathrm{NaCl}$ with two changes. The assay was initiated by the addition of sodium $\left[{ }^{14} \mathrm{C}\right]$ formate (final concentration of $0.61 \mathrm{mM}$, $54.7 \mathrm{mCi} / \mathrm{mmol}$; Amersham Corp., Arlington Heights, Ill.) and incubated at $37^{\circ} \mathrm{C}$ for $4-8 \mathrm{~h}$. The assay was terminated by placing the dishes on ice and quickly washing the cells twice with $3 \mathrm{ml}$ of ice-cold PBS, leaving an additional $0.5 \mathrm{ml}$ of PBS in the dishes. Cells were removed from the surface by scraping with a teflon policeman and added to trichloroacetic acid (TCA) to yield a final concentration of $5 \%$. The cells were extracted on ice for $30 \mathrm{~min}$, then heated for $30 \mathrm{~min}$ at $80^{\circ} \mathrm{C}$ to solubilize the DNA and RNA (9). The tubes were cooled on ice for $15 \mathrm{~min}$ and the resulting protein precipitate, free of nucleic acids, was washed three times with $10 \%$ TCA. The protein pellets were resuspended in $0.4 \mathrm{ml}$ of ultra-pure $6 \mathrm{~N}$ HCl (Alfa Div., Ventron Corp., Danvers, Mass.) and hydrolyzed for $24 \mathrm{~h}$ at $110^{\circ} \mathrm{C}$. The resulting hydrolysate was concentrated by vacuum-evaporation to dryness with a heatlamp and resuspended in $50 \mu \mathrm{l}$ of $\mathrm{H}_{2} \mathrm{O}$. A $10-\mu$ l sample was streaked on cellulose thin-layer chromatography plates with fluorescent indicator (Eastman Kodak Co., Rochester, N. Y.). Met (and its breakdown products Met sulfoxide and Met sulfone) were separated from serine and cysteine (and its products cystine and cysteic acid) in a phenol:ethanol: $\mathrm{H}_{2} \mathrm{O}$ : $\mathrm{NH}_{4} \mathrm{OH}(65: 20: 20: 2)$ one-dimensional solvent system. Since serine condenses with $\mathrm{HC}$ to form cystathionine, which is converted to cysteine, any label that appears in cysteine actually originates from serine. The cold carrier amino acids were visualized using UV light after spraying the plates with fluorescamine (Kontes Co., Vineland, N. J.) and the spots cut out and quantified by liquid scintillation counting in Econofluor (New England Nuclear, Boston, Mass.) at 97\% efficiency. To control unlabeled hydrolysates were added either $\left[{ }^{[4} \mathrm{C}\right]$ methionine, $\left[{ }^{14} \mathrm{C}\right]$ serine, or $\left.{ }^{[35} \mathrm{S}\right]$ cysteine; $98 \%$ of the Met label, $96 \%$ of the serine label, and $97 \%$ of the cysteine label cochromatographed with their respective unlabeled standards. The assay was linear with time in both the normal and the reductase-deficient cell lines to at least $8 \mathrm{~h}$. Duplicate samples agreed within $10 \%$. Leucine (Leu) incorporation into protein was measured in replicate plates by adding $\mathrm{L}-\left[3,4,5-{ }^{3} \mathrm{H}(\mathrm{N})\right]$ leucine $(120 \mathrm{Ci} / \mathrm{mmol}$; New England Nuclear) at a final concentration of $14 \mu \mathrm{M}$. After the TCA precipitation, the precipitate was collected on GF/A glass microfiber filters (Whatman, Inc., Clifton, N. J.) washed three times with $10 \%$ TCA and once with $0.1 \mathrm{~N} \mathrm{HCl}$, dried and counted in Econofluor at 35\% efficiency. Protein was determined by the method of Lowry (10) in a third set of replicate plates. Amino acid analysis by ion exchange chromatography was performed on a Beckman amino acid analyzer (Beckman Instruments, Inc., Fullerton, Calif.).

Lymphoblasts were maintained in logarithmic growth until the day of assay when they were recovered from the RPMI medium by centrifugation and resuspended at a density of $1.5 \times 10^{6}$ cells $/ \mathrm{ml}$ in the Met-free, HC-supplemented medium. $1 \mathrm{ml}$ of the cells was placed in $16 \times 100$-mm glass tubes, flushed with $95 \%$ air- $5 \% \mathrm{CO}_{2}$, capped, and allowed to equilibrate for $1 \mathrm{~h}$. The cells were incubated for $4 \mathrm{~h}$ with the sodium $\left[{ }^{14} \mathrm{C}\right]$ formate at a final concentration of $0.18 \mathrm{mM}$ and the $\left[{ }^{3} \mathrm{H}\right]$ leucine at $8.4 \mu \mathrm{M}$. The reaction was terminated by plunging the tubes into ice water and adding $3 \mathrm{ml}$ of ice-cold PBS. The cells were centrifuged at $500 \mathrm{~g}$ for $10 \mathrm{~min}$ and extracted in $1 \mathrm{ml}$ of $5 \%$ TCA for $30 \mathrm{~min}$. The remainder of the procedure was the same as for the fibroblasts.

Origin of cell lines. Four of the five control fibroblast lines were initiated in our laboratory and the fifth, MGF379, was obtained from the American Type Culture Collection (CLR1125), Rockville, Md. Three of these lines were derived from males and two from females, and the ages of these normal subjects approximated the ages of the $5,10-\mathrm{CH}_{2}-\mathrm{H}_{4} \mathrm{PteGlu}$ reductase-deficient patients. Passage number was controlled for between the normal and mutant cell lines. Three of the $5,10-\mathrm{CH}_{2}-\mathrm{H}_{4} \mathrm{PteGlu}$ reductase-deficient fibroblast lines, viz., MGF451, MGF452, and MGF548, were obtained from Dr. S. H. Mudd and Dr. W. B. Uhlendorf of the National Institutes of Health. Two mutant lines, MGF858 and MGF876, were obtained from the Canadian Repository for Mutant Cell Strains, Montreal, Quebec, Canada, with registry numbers WG735 and WG670, respectively. Cell line MGF735 was obtained from Dr. S. Cederbaum of the University of California, Los Angeles. Line MGF488 was initiated in our laboratory.

The two control lymphoblast lines, MGL8B2 and MGL10, originated in our laboratory. The $5,10-\mathrm{CH}_{2}-\mathrm{H}_{4}$ PteGlu reduc- 
tase-deficient lymphoblast line MGL28 was initiated in Dr. J. Edwin Seegmiller's laboratory at the University of California, San Diego, with log number 1082. Cell line MGL30 was started in our laboratory.

\section{RESULTS}

Table I lists seven patients with $5,10-\mathrm{CH}_{2}-\mathrm{H}_{4}$ PteGlu reductase deficiency from six different families, and with a brief clinical summary, divides them by clinical status into mildly, moderately, and severely affected. Enzyme activity was assayed according to standard procedures (see Methods) in crude extracts of fibroblasts and lymphoblasts derived from the patients. For comparison the normal values for our laboratory are listed at the bottom of the table. The two mildly affected patients have only slightly more residual enzyme activity in their fibroblast extracts than the moderately af- fected siblings ( 1.6 and $1.6 \mathrm{nmol} \mathrm{HCOH} / \mathrm{mg}$ protein per h compared with 1.2 and $1.1 \mathrm{nmol} \mathrm{HCOH} / \mathrm{mg}$ protein per $h$ ), the separation of these two groups of patients by residual enzyme activity thus being small. In fibroblasts from two of the severely affected patients (MGF858 and MGF876), enzyme activity is below the limits of detection by our assay $(0.2 \mathrm{nmol} \mathrm{HCOH} / \mathrm{mg}$ protein per $\mathrm{h})$. The fibroblast extract of the third severely affected patient (MGF735) paradoxically has the highest residual enzyme activity $(2.9 \mathrm{nmol} \mathrm{HCOH} / \mathrm{mg}$ protein per $\mathrm{h}$ ) of any of the patients. The two lymphoblast lines (MGL30 and MGL28) have more enzyme activity than in the corresponding fibroblast lines (MGF548 and MGF451) even after correction for the higher activity in the control lymphoblast lines compared with the control fibroblast lines.

The results of our whole-cell assay for Met biosyn-

TABLE I

Clinical Summary of Seven Patients with 5,10-CH $-\mathrm{H}_{4}$ PteGlu Reductase Deficiency and Enzyme Activity in Fibroblast and Lymphoblast Extracts

\begin{tabular}{|c|c|c|c|c|c|}
\hline \multirow[b]{2}{*}{ Patient } & \multicolumn{2}{|c|}{ Fibroblasts } & \multicolumn{2}{|c|}{ Lymphoblasts } & \multirow[b]{2}{*}{ Clinical summary } \\
\hline & $\begin{array}{l}\text { Cell line } \\
\text { number }\end{array}$ & $\begin{array}{c}5,10-\mathrm{CH}_{2}-\mathrm{H}_{4} \text { PteGlu } \\
\text { reductase activity }\end{array}$ & $\begin{array}{l}\text { Cell line } \\
\text { number }\end{array}$ & $\begin{array}{c}5,10-\mathrm{CH}_{2}-\mathrm{H}_{4} \mathrm{PteGlu} \\
\text { reductase activity }\end{array}$ & \\
\hline & & $\begin{array}{c}\text { nmol } \mathrm{HCOH} / m g \\
\text { protein } / h^{*}\end{array}$ & & $\begin{array}{c}\text { nmol } \mathrm{HCOH} / m g \\
\text { protein } / h^{*}\end{array}$ & \\
\hline W.M. & MGF548 & $1: 6 \pm 0.4$ & MGL30 & $2.9 \pm 0.1$ & $\begin{array}{l}\text { Mildly affected: cerebellar ataxia with mild } \\
\text { spastic quadraparesis; focal seizure } \\
\text { disorder (1) }\end{array}$ \\
\hline C.P. & MGF488 & $1.6 \pm 0.4$ & - & - & $\begin{array}{l}\text { Mildly affected: abnormal gait with decreased } \\
\text { muscle strength and focal seizure disorder } \\
(5,11)\end{array}$ \\
\hline L.M. & MGF451 & $1.2 \pm 0.4$ & MGL28 & $2.1 \pm 0.3$ & $\begin{array}{l}\text { Moderately affected: mental retardation with } \\
\text { schizophrenia-like behavior; moderate } \\
\text { muscle weakness with spasticity }(5,12,13)\end{array}$ \\
\hline B.M. & MGF452 & $1.1 \pm 0.2$ & - & - & $\begin{array}{l}\text { Moderately affected: sister of L.M., also } \\
\text { mentally retarded with peripheral } \\
\text { neuropathy }(1,5,12,13)\end{array}$ \\
\hline S.M. & MGF858 & 0.2 & - & - & $\begin{array}{l}\text { Severely affected: marked psychomotor } \\
\text { retardation with hypotonia; apneic spells } \\
\text { with hypothermia and coma age } 7 \mathrm{mo} \\
\text { alive at } 2 \text { yr (14) }\end{array}$ \\
\hline M.S. & MGF735 & $2.9 \pm 0.2$ & - & - & $\begin{array}{l}\text { Severely affected: presentation in infancy; } \\
\text { marked developmental delay; respiratory } \\
\text { failure age } 15 \mathrm{mo} \text {; alive at } 4 \text { yr } \$\end{array}$ \\
\hline S.S. & MGF876 & 0.2 & - & - & $\begin{array}{l}\text { Severely affected: severe psychomotor } \\
\text { retardation; convulsions with coma at } 6 \\
\text { months; death at } 9 \text { mo (14) }\end{array}$ \\
\hline $\begin{array}{l}\text { Normal } \\
\text { subjects }\end{array}$ & $\begin{array}{l}\text { Average of } \\
\text { five lines }\end{array}$ & $9.0 \pm 2.0$ & $\begin{array}{l}\text { Average of } \\
\text { two lines }\end{array}$ & $11.7 \pm 1.2$ & \\
\hline
\end{tabular}

* Values are the mean with SD of at least three assays performed in duplicate.

$\$$ Personal communication. 
TABLE II

Methionine Biosynthesis by Five Normal and Seven 5,10- $\mathrm{CH}_{2}-\mathrm{H}_{4}$ PteGlu Reductase-deficient

Fibroblast Lines

\begin{tabular}{|c|c|c|c|c|}
\hline \multirow[b]{2}{*}{$\begin{array}{l}\text { Cell line } \\
\text { designation }\end{array}$} & \multicolumn{3}{|c|}{ Methionine synthesis* } & \multirow[b]{2}{*}{ Clinical status } \\
\hline & & & $\frac{\text { Met }}{\begin{array}{c}\text { Total protein } \\
\text { labelf }\end{array}}$ & \\
\hline & $\begin{array}{l}\text { pmollmg } \\
\text { protein/h }\end{array}$ & $\begin{array}{l}\text { pmol/pmol } \\
\text { Leu incorp. }\end{array}$ & percent & \\
\hline MGF287 & $903 \pm 205$ & $172 \pm 52$ & $58 \pm 11$ & Normal \\
\hline MGF297 & $717 \pm 193$ & $163 \pm 53$ & $49 \pm 6$ & Normal \\
\hline MGF316 & $513 \pm 96$ & $117 \pm 6$ & $42 \pm 8$ & Normal \\
\hline MGF344 & $380 \pm 105$ & $102 \pm 7$ & $47 \pm 8$ & Normal \\
\hline MGF379 & $897 \pm 224$ & $197 \pm 66$ & $48 \pm 4$ & Normal \\
\hline $\begin{array}{c}\text { Average of } \\
\text { controls }\end{array}$ & $682 \pm 232$ & $163 \pm 53$ & $49 \pm 6$ & \\
\hline MGF548 & $273 \pm 53$ & $69.5 \pm 11$ & $46 \pm 11$ & $\begin{array}{l}\text { Mildly } \\
\text { affected }\end{array}$ \\
\hline MGF488 & $253 \pm 60$ & $53.8 \pm 1$ & $23 \pm 6$ & $\begin{array}{l}\text { Mildly } \\
\text { affected }\end{array}$ \\
\hline MGF451 & $53 \pm 16$ & $17.3 \pm 6$ & $17 \pm 5$ & $\begin{array}{c}\text { Moderately } \\
\text { affected }\end{array}$ \\
\hline MGF452 & $50 \pm 26$ & $16.3 \pm 5$ & $26 \pm 11$ & $\begin{array}{l}\text { Moderately } \\
\text { affected }\end{array}$ \\
\hline MGF858 & $42 \pm 18$ & $11.8 \pm 3$ & $5 \pm 1$ & $\begin{array}{l}\text { Severely } \\
\text { affected }\end{array}$ \\
\hline MGF735 & $30 \pm 12$ & $10.6 \pm 1$ & $19 \pm 6$ & $\begin{array}{l}\text { Severely } \\
\text { affected }\end{array}$ \\
\hline MGF876 & $21 \pm 15$ & $6.5 \pm 4$ & $8 \pm 2$ & $\begin{array}{l}\text { Severely } \\
\text { affected }\end{array}$ \\
\hline
\end{tabular}

* Values are the mean with $1 \mathrm{SD}$ of at least three separate assays performed in duplicate. Methionine synthesis includes radioactivity recovered in Met, Met sulfoxide, and Met sulfone.

\ Total protein label includes radioactivity recovered in Met (and Met sulfoxide and Met sulfone), serine, and cysteine (and cystine and cysteic acid).

thesis in five normal fibroblast lines are given in Table II. The data are expressed as picomoles of $\left[{ }^{14} \mathrm{C}\right]$ formate incorporated into Met either per milligram of cell protein or, to control for differences among the cell lines in rates of protein synthesis during the incubation period, per picomole of Leu incorporated into cell protein. Because we analyzed only labeled Met that becomes incorporated into protein (and not the free amino acid pool), the latter method of analysis may be more appropriate because the incorporation of the labeled Leu may be subject to the same factors, e.g., dilution. In control experiments we incubated cells with L$\left[\right.$ methyl $\left.-{ }^{14} \mathrm{C}\right]$ methionine and found that $\sim 65 \%$ of the total cellular radioactivity appeared in the protein fraction and thus this method is representative of the Met synthesized by the cells. The percent column demonstrates that, of the formate label that enters the 5,10-
$\mathrm{CH}_{2}-\mathrm{H}_{4} \mathrm{PteGlu}$ pool and then becomes incorporated into Met, about half is in Met and half is in serinecysteine. Complete amino acid analysis of a labeled hydrolysate by ion exchange chromatography and simultaneous determination of radioactivity demonstrated that $>95 \%$ of the label in protein was identifiable as either Met or serine-cysteine. Of the remaining $5 \%$, $\sim 1 \%$ appeared to be in methyl-histidine and the remaining label did not co-elute with any known amino acid.

The bottom half of Table II shows the Met synthetic data of the seven $5,10-\mathrm{CH}_{2}-\mathrm{H}_{4} \mathrm{PteGlu}$ reductase-deficient fibroblast lines. All lines are clearly deficient in Met synthesis when compared with the normal fibroblasts. The cells derived from the two mildly affected patients (MGF548 and MGF488) are easily distinguished from the two moderately affected siblings (MGF451 and MGF452) through the use of this assay of Met synthesis. The moderately affected patients, L.M. and B.M. (from whom cell lines MGF451 and MGF452 were derived, respectively), are sisters and show the expected intrafamily similarities in their rates of Met synthesis. The fibroblasts from the three severely affected patients (MGF858, MGF735, and MGF876) all show marked reductions in Met synthetic capacity. The percentage of the label that enters Met (label in Met/ label in Met plus serine-cysteine $\times 100 \%$ ) shows greater variability than do the absolute rates of Met synthesis. With the exception of line MGF548, however, a considerably smaller proportion of the formate label enters Met in the reductase-deficient cells than in the control cells.

Cell lines MGF548 and MGF488 derived from patients with mild disease have 43 and $33 \%$ of control Met synthesis when expressed as Met synthesized per picomole of Leu incorporated into protein. Both of these values are considerably higher than the residual enzyme activity ( $18 \%$ of control cells) measured in cell extracts. Cell lines MGF451 and MGF452 derived from the moderately affected patients have 11 and $10 \%$, respectively, of control values for Met synthesis, and these numbers compare favorably with residual enzyme activity (13 and $12 \%$ of normal, respectively). The cell lines derived from the three severely affected patients (MGF858, MGF735, and MGF876) all exhibit marked reductions in their Met synthetic capacity $(7$, 6 , and $4 \%$ of controls, respectively) even though cell line MGF735 has $32 \%$ of normal enzyme activity in the cell extract.

In Table III the two $5,10-\mathrm{CH}_{2}-\mathrm{H}_{4} \mathrm{PteGlu}$ reductasedeficient lymphoblast lines are compared with two control lines. Cell line MGL30 has 36\% of the Met synthetic capacity of the control lines, and this corresponds closely to the fibroblast line, which has $43 \%$ of the control value and is derived from the same patient (MGF548). However, MGL28 has 26\% of the Met synthetic capacity of the control lymphoblast lines, and this 
TABLE III

Methionine Biosynthesis by Two Normal and Two 5,10-CH ${ }_{2}-\mathrm{H}_{4}$ PteGlu Reductase-deficient Lymphoblast Lines

\begin{tabular}{|c|c|c|c|c|}
\hline \multirow[b]{2}{*}{$\begin{array}{l}\text { Cell line } \\
\text { designation }\end{array}$} & \multicolumn{3}{|c|}{ Methionine synthesis* } & \multirow[b]{2}{*}{ Clinical status } \\
\hline & & & $\frac{\text { Met }}{\begin{array}{c}\text { Total protein } \\
\text { labelt }\end{array}}$ & \\
\hline & $\begin{array}{l}\text { pmol/mg } \\
\text { protein/h }\end{array}$ & $\begin{array}{l}\text { pmol/pmol } \\
\text { Leu incorp. }\end{array}$ & percent & \\
\hline MGL8B2 & $328 \pm 130$ & $271 \pm 47$ & $43 \pm 2$ & Normal \\
\hline MGL10 & $294 \pm 96$ & $210 \pm 42$ & $46 \pm 1$ & Normal \\
\hline MGL30 & $55 \pm 11$ & $86 \pm 16$ & $30 \pm 1$ & $\begin{array}{l}\text { Mildly } \\
\text { affected }\end{array}$ \\
\hline MGL28 & $61 \pm 2.3$ & $64 \pm 12$ & $21 \pm 3$ & $\begin{array}{c}\text { Moderately } \\
\text { affected }\end{array}$ \\
\hline
\end{tabular}

* Values are the mean with $1 \mathrm{SD}$ of at least three separate assays performed in duplicate. Met synthesis includes radioactivity recovered in Met, Met sulfoxide, and Met sulfone.

$\$$ Total protein label includes radioactivity recovered in Met (and Met sulfoxide and Met sulfone), serine, and cysteine (and cystine and cysteic acid).

does not correspond well to the fibroblast line derived from the same patient (MGF451) who has $11 \%$ of control values.

This same assay was performed in two controls and three of the 5,10- $\mathrm{CH}_{2}-\mathrm{H}_{4}$ PteGlu reductase-deficient fibroblast lines at low concentrations of Met $(1,3,10$, and $30 \mu \mathrm{M}$ ). Although the apparent rates of Met synthesis were lower owing to the dilutional effect of the unlabeled Met, the differences between the normal and the deficient lines remain unchanged. Since the activity of $5,10-\mathrm{CH}_{2}-\mathrm{H}_{4} \mathrm{PteGlu}$ reductase is known to be higher in confluent cells than in logarithmically growing cells (15), the assay was also performed once in three normal and in two deficient fibroblast lines after $7 \mathrm{~d}$ at confluency. Although one of the normal lines doubled its rate of Met biosynthesis compared with the usual assay conditions at late log growth, the other two normal lines showed no significant change. The two reductasedeficient lines showed small but insignificant increases in rates of Met biosynthesis.

All the $5,10-\mathrm{CH}_{2} \mathrm{H}_{4} \mathrm{PteGlu}$ reductase-deficient cell lines had normal Met synthetase $\left(5-\mathrm{CH}_{3}-\mathrm{H}_{4}\right.$ PteGlu: homocysteine cobalamin methyltransferase) activity (16). To be certain that fibroblast line MGF735 might not represent a deficiency of some other enzyme of the folate path way, the cellular extract was also assayed for activity of $5,10-\mathrm{CH}=\mathrm{H}_{4}$ PteGlu cyclohydrolase (17), $5,10-\mathrm{CH}_{2}-\mathrm{H}_{4}$ PteGlu dehydrogenase (17), serine hydroxymethyltransferase (18), and $10-\mathrm{CHO}-\mathrm{H}_{4} \mathrm{PteGlu}$ synthetase (17). In each instance the activity was similar to control values (data not shown). In addition, line MGF735 exhibited the same poor growth pattern in Met-free, HC-supplemented medium as did other 5,10- $\mathrm{CH}_{2}-\mathrm{H}_{4}$ PteGlu reductase-deficient fibroblast lines. The detailed description of patient M.S. is in preparation by Dr. S. Cederbaum. ${ }^{2}$

\section{DISCUSSION}

The studies we report here clearly demonstrate that fibroblasts and lymphoblasts from $5,10-\mathrm{CH}_{2}-\mathrm{H}_{4} \mathrm{PteGlu}$ reductase-deficient patients exhibit decreased capacity to synthesize Met from HC. The magnitude of the defect in Met synthesis accurately reflects the clinical status of the patients from whom the cells were derived. Met synthesis from HC in human fibroblasts is completely dependent on $5,10-\mathrm{CH}_{2}-\mathrm{H}_{4} \mathrm{PteGlu}$ reductase activity since there is no detectable betaine homocysteine methyltransferase activity (19).

The disparity between the measured Met synthesis (average, $38 \%$ of normal) and the measured residual enzyme activity in the extracts (18\% of normal) in the cells derived from the mildly affected patients is striking and of interest. Met synthesis from HC is directly under the control of the enzyme Met synthetase. The product of the $5,10-\mathrm{CH}_{2}-\mathrm{H}_{4} \mathrm{PteGlu}$ reductase reaction is $5-\mathrm{CH}_{3}-\mathrm{H}_{4} \mathrm{PteGlu}$, a substrate along with $\mathrm{HC}$ in the Met synthetase reaction. It appears that $18 \%$ of normal reductase activity can generate enough $5-\mathrm{CH}_{3}-\mathrm{H}_{4} \mathrm{Pte}-$ Glu to support Met synthesis at a rate $\sim 40 \%$ of normal. Perhaps only $30-40 \%$ of $5,10-\mathrm{CH}_{2} \mathrm{H}_{4}$ PteGlu reductase activity is required to maintain Met synthesis at near normal rates and hence such a mutation would not be clinically apparent. This is consistent with our observation that fibroblasts from heterozygous parents of reductase-deficient patients grow at normal rates in medium in which $\mathrm{HC}$ replaces Met (unpublished data).

As has been widely believed and elegantly demonstrated in the case of Yoshida's studies (20) on glucose6-phosphate dehydrogenase deficiency, the residual enzyme activity measured in an in vitro extract under potentially nonphysiologic conditions may correlate poorly with the severity of the phenotypic disturbance. He showed that a measurement of the physiologic activity of the enzyme may correlate better with the clinical status of the patient. Although patient M.S. in our studies is severely affected clinically, her fibroblast line (MGF735) has $32 \%$ of normal $5,10-\mathrm{CH}_{2} \mathrm{H}_{4} \mathrm{PteGlu}$ reductase activity as measured in a crude cell extract. The Met synthetic capacity of her fibroblast line, however, is only $6.5 \%$ of normal values and very similar to the other two lines derived from severely affected children.

Patient S.S. died at 9 mo of age. Her fibroblast line (MGF876) synthesized Met at 4\% of normal values, the lowest rate of any line studied. The data suggest that

\footnotetext{
${ }^{2}$ Personal communication.
} 
$>4 \%$ of normal Met synthetic capacity as measured in our whole cell system is necessary for survival.

The poor correlation of Met synthetic rates in lymphoblast line MGL28, 26\% of normal, with the Met synthetic function in the fibroblast line derived from the same patient, MGF451, $11 \%$ of normal, is unexplained. It is known that the transformation of human fibroblasts by simian virus $\mathbf{4 0}$ may also be associated with altered rates of Met biosynthesis and Met requirements (21). Perhaps Epstein-Barr virus transformation of human lymphocytes likewise is associated with changes in rates of Met biosynthesis. Alternatively, this discrepancy might be due to tissue specific differences in expression of the enzyme defect caused by factors such as those identified by Yoshida.

Patients with $5,10-\mathrm{CH}_{2}-\mathrm{H}_{4} \mathrm{PteGlu}$ reductase deficiency present clinically with neurologic dysfunction of variable degree. The etiology of their neurologic disturbance is unclear but may relate to altered metabolism of neurotransmitters (13). Many of the neurotransmitters undergo methylation in their synthesis and the main intracellular donor of methyl groups is $S$-adenosylmethionine (AdoMet). Methionine and adenosinetriphosphate are the precursors of AdoMet. The brain, like any other organ, meets its requirement for Met either by uptake from the blood or endogenous synthesis (22). We have demonstrated decreased Met synthetic capacity in $5,10-\mathrm{CH}_{2}-\mathrm{H}_{4} \mathrm{PteGlu}$ reductase-deficient fibroblasts and lymphoblasts and postulate a similar decrease in the brain cells of these patients, leading to inadequate AdoMet generation for normal neurotransmitter synthesis.

\section{ACKNOWLEDGMENTS}

We gratefully acknowledge the cooperation of $S$. Cederbaum J. M. Freeman, S. H. Mudd, D. S. Rosenblatt, H. Singer, V. E. Shih, J. A. R. Tibbles, and W. B. Uhlendorf for help in obtaining blood and skin samples, and for clinical information concerning the patients. We thank M. Magner and M. Tessier for expert technical assistance, and L. Jalbert and M. Quinlan for help in preparing this manuscript.

This work was supported in part by grant HD06356 from the National Institute of Child Health and Human Development.

\section{REFERENCES}

1. Erbe, R. W. 1979. Genetic aspects of folate metabolism Adv. Hum. Gen. 9: 293-354.

2. Kutzbach, C., and E. L. R. Stokstad. 1971. Mammalian methylenetetrahydrofolate reductase: partial purification, properties, and inhibition by S-adenosylmethionine. Biochim. Biophys. Acta. 250: 459-477.

3. Narisawa, K., Y. Wada, T. Saito, H. Suzuki, M. Kudo, T. Arakawa, N. Katsushima, and R. Tsuboi. 1977. Infantile type of homocystinuria with $\mathrm{N}^{5,10}$-methylenetetrahydrofolate reductase defect. Tohoku J. Exp. Med. 121: 185-194.

4. Rosenblatt, D. S., B. A. Cooper, S. Lue-Shing, P. W. K. Wong, S. Berlow, K. Narisawa, and R. Baumgartner. 1979. Folate distribution in cultured human cells. J. Clin. Invest. 63: 1019-1025.
5. Mudd, S. H., B. W. Uhlendorf, J. M. Freeman, J. D. Finkelstein, and V. E. Shih. 1972. Homocystinuria associated with decreased methylenetetrahydrofolate reductase activity. Biochem. Biophys. Res. Commun. 46: 905-911.

6. Kanwar, Y. S., J. R. Manaligod, and P. W. K. Wong. 1976. Morphologic studies in a patient with homocystinuria due to 5,10-methylenetetrahydrofolate reductase deficiency. Pediatr. Res. 10: 598-609.

7. Sly, W. S., G. S. Sekhon, R. Kennett, W. F. Bodmer, and J. Bodmer. 1976. Permanent lymphoid lines from genetically marked lymphocytes recovered from frozen storage. Tissue Antigens. 7: 165-169.

8. Rosenblatt, D. S., and R. W. Erbe. 1977. Methylenetetrahydrofolate reductase in cultured human cells. I. Growth and metabolic studies. Pediatr. Res. 11: 1137-1141.

9. Kennell, D. 1968. Use of filters to separate radioactivity in RNA, DNA, and protein. Methods Enzymol. 12A: 686-693.

10. Lowry, O. H., N. J. Rosebrough, A. L. Farr, and R. J. Randall. 1951. Protein measurement with the Folin phenol reagent. J. Biol. Chem. 193: 265-275.

11. Shih, V. E., M. Z. Salam, S. H. Mudd, B. W. Uhlendorf, and R. D. Adams. 1972. A new form of homocystinuria due to $\mathrm{N}^{5,10}$-methylenetetrahydrofolate reductase deficiency. Pediatr. Res. 6: 135.

12. Freeman, J. M., J. D. Finkelstein, and S. H. Mudd. 1975. Folate-responsive homocystinuria and "schizophrenia," a defect in methylation due to deficient 5,10methylenetetrahydrofolate reductase activity. N. Engl.J. Med. 292: 491-496.

13. Singer, H. S., I. Butler, S. Rothenberg, D. Valle, and J. Freeman. 1980. Interrelationships among serum folate, CSF folate, neurotransmitters, and neuropsychiatric symptoms. Neurology. 30: 419.

14. Rosenblatt, D. S., J. P. Harpey, and B. A. Cooper. 1980. Therapeutic response in a severely affected infant with homocystinuria due to 5,10-methylenetetrahydrofolate reductase deficiency. Am. J. Hum. Genet. 32: 52A.

15. Rosenblatt, D. S., and R. W. Erbe. 1973. Reciprocal changes in the levels of functionally related folate enzymes during the culture cycle in human fibroblasts. Biochem. Biophys. Res. Commun. 54: 1627-1633.

16. Kamely, D., J. W. Littlefield, and R. W. Erbe. 1973. Regulation of 5-methyltetrahydrofolate:homocysteine methyltransferase activity by methionine, vitamin $B_{12}$, and folate in cultured baby hamster kidney cells. Proc. Natl. Acad. Sci. U. S. A. 70: 2585-2589.

17. Tan, L. U. L., E. J. Drury, and R. E. Mackenzie. 1977. Methylenetetrahydrofolate dehydrogenase-methenyltetrahydrofolate cyclohydrolase-formyltetrahydrofolate synthetase. J. Biol. Chem. 252: 1117-1122.

18. Taylor, R. T., and H. Weissbach. 1965. Radioactive assay for serine transhydroxymethylase. Anal. Biochem. 13: 80-84.

19. Finkelkstein, J. D. 1974. Methionine metabolism in mammals: the biochemical basis for homocystinuria. Metab. Clin. Exp. 23: 387-398.

20. Yoshida, A. 1979. Hemolytic anemia and G6PD deficiency. Science (Wash. D. C.). 179: 532-537.

21. Hoffman, R. M., and R. W. Erbe. 1978. High in vivo rates of methionine biosynthesis in transformed human and malignant rat cells auxotrophic for methionine. Proc. Natl. Acad. Sci. U. S. A. 73: 1523-1527.

22. Zeisel, S. H., and R. J. Wurtman. 1979. Dietary intake of methionine: influence on brain S-adenosylmethionine. In Transmethylation. E. Usdin, R. T. Borchardt, and C. R. Creveling, editors. Elsevier/North-Holland, New York. 59-68. 